\title{
Study on the Future Development Plan of Zhuhai International Urban Business Circle in Guangdong- Hong Kong-Macao Great Bay Area
}

\author{
Yang Li \\ School of Art \\ Zhuhai College of Jilin University \\ Zhuhai, China
}

\begin{abstract}
Guangdong-Hong Kong-Macao Great Bay Area refers to the urban agglomeration composed of 9 cities including Guangzhou, Foshan, Zhaoqing, Shenzhen, Dongguan, Huizhou, Zhuhai, Zhongshan, Jiangmen and Hong Kong and Macao. The economic effect derived from it is called "bay area economy", and the international business circle brought about by bay area economy also followed. The project makes a comparison between Zhuhai business circle with world-class ones by analyzing the current status of it and concludes the differences and deficiencies. A future development plan specific to the differentiation is made, which firstly needs one or two core business circles lead in development, maturity, and agglomeration of elements and resources. When it develops to a certain stage, it can radiate and drive the development of various types of small and medium business circle around through economic link of hardware and software. When the core business circle becomes larger, stronger and more, the effect of it on the surroundings will be stronger.
\end{abstract}

Key words-Guangdong-Hong Kong-Macao Great Bay Area; Zhuhai urban business circle; plan

\section{INTRODUCTION}

Report on the work of the government in 2017 proposes to study the development plan of urban agglomeration in Guangdong-Hong Kong-Macao Great Bay Area. "This makes Guangdong-Hong Kong-Macao Great Bay Area construction become the focus of public opinion again. As one of the starting point of the Silk Road, Guangdong-Hong Kong-Macao Great Bay Area, with its special history and culture and location advantages, bears the strategic intentions of "one belt and one road" and opening up of our country, which will inevitably lead to the rapid development of business. After the research, the author finds that there has not been a mature international urban business circle in Zhuhai.

Zhuhai has the history and culture to develop to an international urban business circle. Zhuhai, as a member of Guangdong-Hong Kong-Macao Great Bay Area, is not only an important part that cannot be ignored, but also a part that with historical and cultural deposit. About 150 years ago, in the region of Zhuhai, process of modern Chinese history is

This paper is supported by Innovative Ability Cultivation Project of Zhuhai College of Jilin University (2017XJCQSQ021) opened, which opened a window for the Chinese people to see the world in the closed doors of the high wall under the barrier. Moreover, the birthplace of all this is not the three cities of Hongkong, Guangzhou and Shenzhen we are arguing now, nor the current leading east coast, but it is the inconspicuous west coast at the moment In that year, the tide of the west coast of Pearl River constantly promote China's modernization.

At the same time, Zhuhai also has the location advantages of developing to an international urban business circle. Construction of Guangdong-Hong Kong-Macao Bridge will form the land port to Hangkong in west coast of Pearl River, which can form a linkage with the five land port to Hong Kong in the east coast of Pearl River, resolving the unbalanced development between east and west coast of Pearl River to a certain extent. It will further promote the urban circle in west coast of Pearl River to better integrate into the Guangdong-Hong Kong-Macao great Bay Area greatly driving the economic development of urban circle in west coast of Pearl River. Therefore, it brings a great convenience and a better opportunity to the development of urban business in Zhuhai.

\section{RESEARCH PURPOSES AND ACADEMIC APPLICATION VALUE}

\section{A. Research Purposes}

Bay area refers to the area consisting of a bay or a number of gulfs, harbors, and islands nearby. In today's world, the bay Area has become an important growth point of global economic development and a leader of technological change. The economic effect derived from it is called "bay area economy" and the international business circle brought about by bay area economy also followed. At present, Guangdong-Hong Kong-Macao great Bay Area possesses the basic conditions to be built into a world-class Bay and the world-class urban agglomeration, and gradually develop into the engine of global economic development, gathering place of global talent, vigor area of the global innovation and entrepreneurship and international great bay Area. It will be ranked among the world's four major Bay area, comparing to Tokyo Bay area, New York Bay area and San Francisco Bay Area. Besides, one of the world's top five 
golden business circle-- New York Fifth Avenue will be an important symbol of world's typical shopping paradise in New York City without exception. It can be said that to a large extent, shopping paradise is reflected in a number of well-known landmark business circles. Most of these business circles are well-built, representing the city's biggest commercial highlights, which is an area with growth, the highest land rent, the most representative of the business trend of the city, as well as a lot of history, culture, entertainment, food, leisure experience and other functions.

Although Zhuhai is an important part of the Bay Area, as well as an early coastal city with reform and opening up, there is still a large distance from the advanced and mature international business circle. Therefore, this project summarizes the shortcomings of Zhuhai through the study on present situation and comparative analysis with smart business circle format implanted, and creates the future development plan to popularize the Zhuhai International urban business circle to the country and the world. Zhuhai not only has a high level Hengqin Auto Trade Area, Hong Kong-Zhuhai-Macao Bridge and Gongbei, Hengqin port and other cross-border channel, but also explores a lot of institutional innovation in deepening Hong Kong-ZhuhaiMacao industrial cooperation and collaborative development and other fields. It has become an important node in Hong Kong and Macao. "Overall planning" determines the administrative area of 7653 square kilometers as urban planning area. The main city consists of the central city (including the old and new Xiangzhou, Jida, Gongbei, Qianshan and other areas) and South Bay urban area (including Nanping, Wan Chai, Hongwan and other areas). The central city mainly develops tertiary industry, continuing to evacuate some industries in accordance with the requirements of "Overall planning"; South Bay City mainly develops secondary industry. The strong government planning support undoubtedly brings opportunities for Zhuhai to become an international urban business circle. The establishment of Zhuhai International urban business circle can not only build a new image in the background of Great Bay Area, but also bring economic and cultural benefits to the development of Zhuhai itself and Great Bay Area.

\section{B. Academic Application Value}

Each city has its own commercial coordinate system. There is no exception with Zhuhai. In recent years, with the improvement of living standard, Zhuhai's business circle is constantly expanding the city map to make their business system more mature in order to meet the needs of the higher living expenses of the public. However, because of terrain, population distribution, policy planning, the lagging economic development and the different level of customer groups, business development in Zhuhai encounters limitations, and the commercial market is not yet fully mature. Ratio of catering and leisure entertainment function area is severely low, with single type and small scale. Moreover, the comprehensiveness of existing major shopping malls is not high, and the format is not complete, which is difficult to meet the one-stop consuming demand of various types of consumers. Above is what Zhuhai business need to be improved currently. Therefore, aiming at this situation and the problems, this project not only creates a shopping place that meets the needs of the public, but also lays the foundation for the great bay area to become international.

\section{PlANNING FOR ZHUHAI INTERNATIONAL URBAN BUSINESS CIRCLE}

\section{A. Project Positioning}

Market positioning: one-stop international urban leisure business circle

Functional positioning: smart business circle format that integrates shopping, leisure, catering, entertainment, performing arts, cultural experience into one.

Image positioning: international cultural business model with fashion, vitality, and experience.

Positioning of target customer base: domestic and foreign customers from all walks of life at the age of $15-65$.

Through the main core business district and Nanwan business district, it connects Zhongshan in the north, is separated from Macao by a river in the East, joins Doumen in the West, and links Hengqin Island Bridge in the South. The area of the city is about 70 square kilometers area. Today's South Bay, with noble residential area gathered and returned park crossed, has pleasant scenery and intensive traffic network. The construction of sub-core business circleHengqin business circle establishes the brand image of Zhuhai international urban business circle, radiating to the surrounding small business circles. The first generation of single store proposes model of order-based real estate; the second generation of combination shores introduces a number of combo stores, with customer base diversified; the third generation of city complex introduces a variety of properties to improve the rate of return on investment and avoid dispute by renting instead of selling. See "Fig. 1".

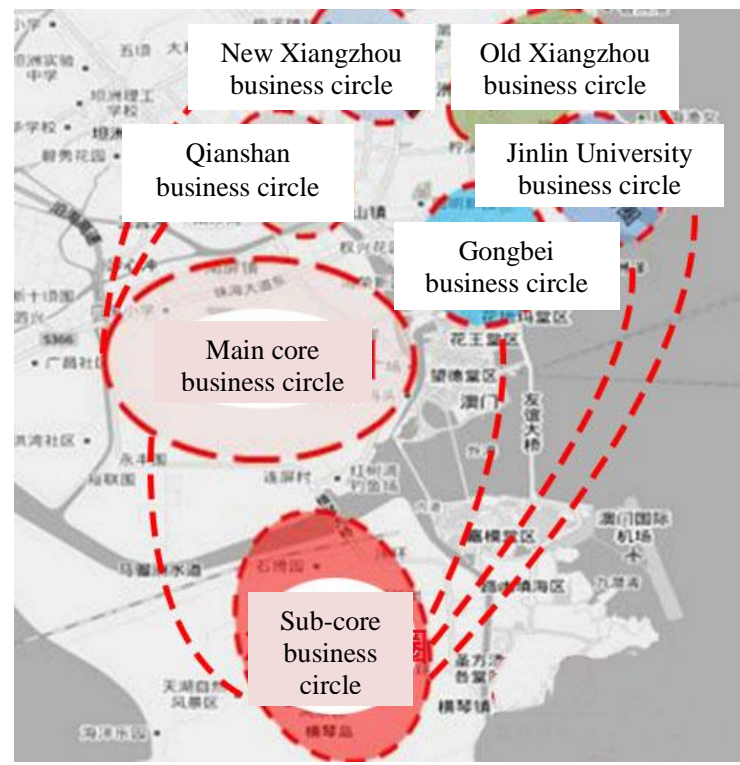

Fig. 1. Planning for Zhuhai Business circle. 


\section{B. Project Promotion}

Promotion is conducted in three stages:

1) The first stage: product brand marketingcompetition of location, price and product itself: As the starting stage, Zhuhai has the basic conditions for development of business circle. However, the capacity of previous business circle is smaller, the number of largescale branches is less, and industry format is not perfect with relatively single function and small radiation range, so the traffic is relatively small, lacking business atmosphere. Therefore, we re-established the brand model. As shown in "Table I".

TABlE I. Planning For Structure of the Business Circle

\begin{tabular}{|c|c|c|}
\hline Floor & Function Positioning & Advice \\
\hline B2 & large parking lot & $\begin{array}{l}\text { Obvious elevator and staircase } \\
\text { entrance mark, accurate and easy } \\
\text { pavement instructions and guidance }\end{array}$ \\
\hline$B 1$ & $\begin{array}{l}\text { Area for teenagers } \\
\text { fashionable supplies } \\
\text { Including clothing, shoes } \\
\text { and hats, boutique, IT } \\
\text { audio and video } \\
\text { products, specialty food } \\
\text { and large chain } \\
\text { supermarket }\end{array}$ & $\begin{array}{l}\text { Introduce various types of hand } \\
\text { workshops, model aircraft, and } \\
\text { handicraft production training } \\
\text { courses. Organize various youth } \\
\text { activities with the Children's Palace } \\
\text { and Hong Kong and Macao } \\
\text { organizations jointly, and set up } \\
\text { youth activities base. }\end{array}$ \\
\hline$F 1$ & $\begin{array}{l}\text { World famous high-end } \\
\text { brand fashion items, } \\
\text { including clothing, } \\
\text { footwear, cosmetics, } \\
\text { leather goods, boutique } \\
\text { mainly for female users }\end{array}$ & $\begin{array}{l}\text { Make use of the arcade cultural } \\
\text { square architectural features in the } \\
\text { mall street shop and build centered } \\
\text { large fountain, open-air and indoor } \\
\text { connected tea house, and coffee } \\
\text { lounge to connect to second floor. } \\
\text { Increase the leisure and sightseeing } \\
\text { function of shopping mall. }\end{array}$ \\
\hline$F 2$ & $\begin{array}{l}\text { World famous and high- } \\
\text { end brand fashion } \\
\text { supplies for male users }\end{array}$ & $\begin{array}{l}\text { Supermarket led by world's retail } \\
\text { giant and department stores will } \\
\text { gather a lot of people. }\end{array}$ \\
\hline $\begin{array}{l}\text { F3 } \\
\text { (east } \\
\text { and } \\
\text { south) }\end{array}$ & $\begin{array}{l}\text { Fancy food with Zhuhai } \\
\text { features and all kinds of } \\
\text { high-level western } \\
\text { restaurant gathered. }\end{array}$ & $\begin{array}{l}\text { To promote food consumption by } \\
\text { traditional Zhuhai cuisine and } \\
\text { Zhuhai special art performances. } \\
\text { Various kinds of high-level western } \\
\text { restaurant gathered are easy for } \\
\text { customers to find. }\end{array}$ \\
\hline $\begin{array}{l}\text { F3 } \\
\text { (west } \\
\text { and } \\
\text { north) }\end{array}$ & $\begin{array}{l}\text { Distributing center of } \\
\text { Zhuhai special travel } \\
\text { handicraft stores, silk, } \\
\text { ethnic costumes, antique } \\
\text { jade, calligraphy and } \\
\text { painting, Chinese herbal } \\
\text { medicines and all kinds } \\
\text { of domestic and } \\
\text { international sports } \\
\text { brand. }\end{array}$ & $\begin{array}{l}\text { To introduce jade Street, thirteen } \\
\text { lines and other characteristic } \\
\text { business operators, and attract 1-2 } \\
\text { branded tourism companies to } \\
\text { provide various services. In the } \\
\text { meanwhile, establish professional } \\
\text { authority to display, sell and } \\
\text { appraise the handicrafts, and } \\
\text { supervise, manage and promote it. } \\
\text { To set up Jinwan Art Association to } \\
\text { attract experts all over the world to } \\
\text { communicate and trade so as to } \\
\text { enhance the operating level. }\end{array}$ \\
\hline F4 & $\begin{array}{l}\text { Attract } \text { Guangdong } \\
\text { brand restaurant, such as } \\
\text { Tao Tao Ju Restaurant, } \\
\text { Northr Garden } \\
\text { Restaurant, Caigenxiang } \\
\text { Restaurant Guangzhou } \\
\text { Restaurant and so on. }\end{array}$ & $\begin{array}{l}\text { Equip the center with large Chinese } \\
\text { restaurant and special snack street, } \\
\text { five-star cinema, star-class SPA, } \\
\text { game center to let people fully } \\
\text { enjoy the charm of shopping mall } \\
\text { while shopping. }\end{array}$ \\
\hline F5 & Serviced apartment & $\begin{array}{l}\text { To support the business center and } \\
\text { entertainment center }\end{array}$ \\
\hline
\end{tabular}

Plan and design of the buildings in business circle:

The building of business circle should follow the principle of uniformity and integrity, which is reflected in the overall style, shape and color of the buildings. Moreover, the buildings should be coordinate with surrounding buildings and environment, according to the project positioning and operating characteristics. Attentions should be paid to the layout of decorative wares and interior furnishing style reflects the operating features of each floor.

The first floor adopts arcade and two to three ones use enclosed type. The decoration craft should be traditional and plentiful, including Lingnan wood carving, stone carving, tile carving, clay carving, lime sculpture, fresco, iron ornamental work and glass. The street is covered by granite tile and the wall is mainly covered by black brick as parapet equipped with various kinds of splendid Manzhou windows. The style combines western and European architectural features. Lay emphasis on the night effect of the buildings, lighting and shadow, as well as the collocation of wall and other colors to form the perfect combination of ancient and modern times. The first floor is designed mainly as waterscape and greening. As commercial real estate, we deem that the construction of waterscape is very necessary since the saying goes, "water is for money". It is recommended two waterfalls built in the 4-1 of East and West Block. The waterfalls fly from the 4th floor to the first one. There are two reservoirs on the ground first floor and connect a mobile waterway, to create a beautiful landscape.

Lead into 3D garden effects by using landscape to make overlapping design and plant various kinds of flowers and plants of Lingnan on the overlapping platform. Upper layer of windows on each layer adopt deep arch design, which not only let the sun illuminate the room, but also can enhance the lighting and permeability. Besides, as for the bunker structure, one 2-meter channel is reserved between every 4-5 shops. The use of full-height glass as enclosure and seats for the customers can not only make people clearly see the landscape and scene on the street, but also make the space more stereoscopic.

2) The second stage: service marketing-- competition of anti-rent, operating management, main stores and added value of products: As growing stage, the municipal auxiliary facilities is completing gradually, capacity of the business circle is getting larger, number of business branches is constantly increasing, large branches are introduced, every kinds of business are improving, function is getting stronger, radiant scale is expanding and customer volume are increasing. The business atmosphere is formed generally. In order to attract more shops, we introduce the commercial service system so that settled shops have an editable independent account in the system. They can publish customized related product information, promotional information, event announcements, discounts and other dynamic information in accordance with established formats. Then off-line shops and products 
resources can be integrated into on-line gradually. The users can get the relevant information by entering the page. Meanwhile, users can learn more information they are interested in, and communicate with the business online to achieve a good consumer experience; users will have their own account information after registration, where they can collect interesting information, search consumption records, points information, etc.; opening up of microblog, QQ and other social platforms enable users to share information to the social platform, interact with friends to achieve multichannel promotion; we can also proactively push the information according to time, login frequency, consumption records, browsing preferences, membership level and other data information.

3) The third stage: experience marketing-competition of smart business format, situational shopping, theme shopping and customer simulating investment: In mature stage, the business circle reaches saturation point. Implantation of smart business format structure optimize the branches network structure, strengthen the business atmosphere, stabilize the consumer groups and flow volume, and make the business circle prosperous.

a) Wireless network in the business circle provides free WIFI service: Construct basic network facility in the smart business circle, lay AP equipment rationally in the public area of the core business circle to achieve full coverage of regional WIFI, giving consumers a good internet experience in the business circle. The band width can be improved timely according to the using condition of Internet later to expand the Internet capacity and optimize the surfing experience.

b) The basic platform of business circle data achieves interaction between business circles: Provide stable, unified platform service and standard open interface for the smart business applications through the smart business circle platform to make parking services, business applications, government services, query and other intelligent services access to the platform conveniently and fast. At the meantime, good expansibility of the platform also supports the business to develop their own APP so that collection of various data can be achieved and business circle database will be established. Users can find the goods they need quickly and accurately through the mobile phone, and interact with the business in the circle on product information, promotional information and shop introduction in time, which can promote sales and comparability and transparency of consumption; users can get in touch with other users who are interested in the same product and chat with them through the business circle APP; business can push discount promotional information targeted to the consumers with high consumption frequency and strong consuming willingness.

c) Large intelligent terminal equipment: Aiming at image display, attracting users and businesses, intelligent terminals are placed around the business circle for users to search consumer information and shopping guidance.
What's more, the large intelligent terminal equipment can also show the related governmental information and other handy service for the public.

\section{Project Execution Plan}

Initial driving of the market and attracting market attention can be achieved through various marketing activities, including publicity on traditional media and new media; in hot sale of market stage, newspapers, magazines, outdoor advertising and other means of publicity can be adopted.

Publicity of main shops can increase the confidence of investors visually; earnings from leaseback attract continuous investment; promotion activities, sending and discount can simulate purchasing; market liquidation means basic project sale is completed.

\section{CONCLUSION}

Guangdong-Hong Kong-Macao Great Bay Area has the basic condition to be a world-class Bay area and the worldclass urban agglomeration. Design research on Zhuhai International urban business circle under the background of the great bay area is conducive to the positioning of Zhuhai in the great bay area and can help drive the development and deep cooperation and exchanges from the aspects of manufacturing, services, economy and trade and finance. In addition, construction of Zhuhai international urban business circle can attract innovative entrepreneur industry, incubation base and science and technology center to enter. Thanks to the location adjoining Macao, it can not only promote youth innovative entrepreneurship and diversified development of industry, but also provide a opening platform for Zhuhai. Introduction of smart business circle format brings about application value and business value such as drainage of business circle, business navigation, business interaction and big data of business circle. Building of smart business circle can provide accurate big data marketing service and improve the brand recognition and coverage area of businesses.

\section{REFERENCES}

[1] Wu Zongqing, Chai Yanwei, "On some problems about study on structure of urban business activity space," Economic Geography, vol 1, 2000.

[2] Hu Xin, Zhao Ying, "Study on positioning of business circle in urban sub-center," Urban Development Research, vol. 6, 2003.

[3] Zhang Bing, "Study on construction of business circle," Chongqing University, 2005.

[4] Wu Xiaoding, "Huff model and analytical method of structure of urban business circle," Economics of Finance and Trade, vol. 3, 2001.

[5] Sun Yuanxin, "Theory and comments of foreign business programming," Commercial Research, vol. 23, 2003. 